\section{HIGHWAY DEVELOPMENT AFFECTS THE POPULATION OF THE INDIAN FLYING FOX Pteropus giganteus (BRUNNICH, 1782)}

\author{
C. Srinivasulu and Bhargavi Srinivasulu \\ Wildlife Biology Section, Department of Zoology, Osmania \\ University, Hyderabad, Andhra Pradesh 500007, India. \\ Email:masawa@hd2.dot.net.in
}

Deserting of traditional roosts by the Indian Flying Fox Pteropus giganteus (Brunnich, 1782) due to the presence of large beehives on the roosting tree has been earlier reported (Srinivasulu \& Srinivasulu, 2002). It may be possible that numerous such natural causes might lead to the desertion of the traditional roosts. The human angle, that has been recently added to compound the pressure, too is indeed detrimental in the loss of roosting habitats. This is evident and has been well documented scientifically among microchiropetrans (Hutson et al., 2001; Mickleburgh et al., 2002). Through this write up we present our observations on anthropogenic causes that has lead to population decline and roost desertion by Pteropus giganteus.

Of the four Pteropus giganteus camps we were monitoring within a 30-km radius of Hyderabad (Srinivasulu \& Srinivasulu, 2002), the present observation relates to the camp located at Goudvelly, $27 \mathrm{~km}$ from Hyderabad, in Ranga Reddy District. The senior author has been observing this camp since late 1992, and we have maintained half-yearly counts from 1997 onwards. The camp is located on a large banyan Ficus bengalensis tree in the southeastern border of the village. One reliable source had informed us of the presence of around 1000 plus individuals on this tree. From 987 individuals in our first count to zero during the last count, the decline is baffling (Fig. 1).

Three major catastrophes have affected the present population since 1995. The first event being breaking of a main branch of the roosting tree, as a result of strong winds. About 270 individuals using the branch were displaced, and some of the individuals that could not accommodate on other branches simply migrated to other roosts. This resulted in a $40 \%$ decline of the population on that tree. During the winter of 2000, the owners of the land, in which the roosting tree was located, resorted to killing of the bats to scare the remaining away. This occurred over a period of two months, and resulted in $62 \%$ decline of the population.

The third major event that was more detrimental than the former causes happened over a period of time from 2001 onwards. The National Project on Highway development commenced in this region and the roadside trees were felled. Among the trees that were gone were the main food resource plants. With their food resources gone, the bats

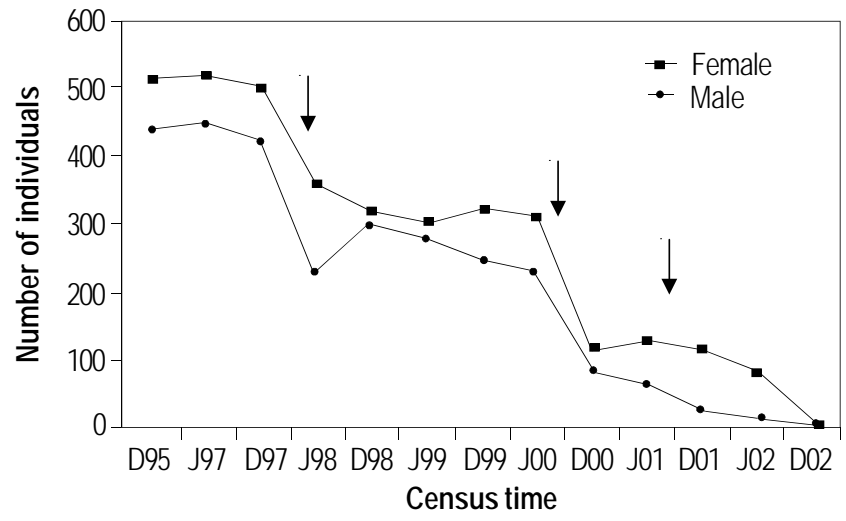

Note: The arrows indicate periods of calamities that have affected the population; the males responded greater than females and deserted the roost more in numbers than females indicating roost fidelity being more in females.

J - July; D - December

\section{Fig. 1. Population fluctuations of male and female Pteropus giganteus between 1995 and 2002}

were under stress as a result of higher energy expenditure for food gain. This over the span of time, coinciding with ongoing tree felling, has resulted in steady decline in Pteropus giganteus population here. With almost all the trees gone, the bats have also disappeared.

The implementation of the Central Government's National Highway Project has resulted in loss of roosting and feeding resources to innumerable faunal elements throughout India. An infinite number of fruit-bearing trees, especially belonging to the Ficus and Syzygium genera, were felled in many localities. With an average of 20 such trees per kilometer, the magnitude of the loss in the light of the total length of the highways running throughout the country is incomparable and irreparable. Our observations shows that in a stretch of $13 \mathrm{~km}$ outside Secunderabad on the National Highway, 102 Ficus bengalensis trees used to support an average of 100 individuals of Pteropus giganteus and many individuals of Cynopterus sphinx. With the area being cleared of trees now, the sighting of the Pteropus giganteus has become increasingly rare.

\section{Acknowledgements}

We thank the Head, Department of Zoology, Osmania University and Prof. V. Nagulu for facilities, and acknowledge individual research grants for both of us from CSIR, New Delhi.

\section{Reference}

Hutson, A.M., S.P. Mickleburgh and P.A. Racey (2001). Microchiropteran Bats: Global status, Survey and Conservation Action Plan. IUCN/SSC Chiroptera Specialist Group, IUCN Gland, Switzerland and Cambridge, UK. X+258 pp.

Mickleburgh,S.P., Houston, A.M. and Racey,P.A.(2002). A review of global conservation status of bats. Oryx 36(1): 18-34.

Srinivasulu, C. and B. Srinivasulu (2002). Indian Flying Fox Pteropus giganteus (Brunnich, 1782) deserting its traditional roosting site. Bat Net CCINSA Newsletter 3(2): 2. 